\title{
Produção e conservação escolar da masculinidade no romance $O$ Ateneu
}

\author{
RITA DE CÁSSIA MARCHI \\ Fundação Universidade Regional de Blumenau, Blumenau, SC, Brasil
}

TIAGO RIBEIRO SANTOS

Universidade Federal de Santa Catarina, Florianópolis, SC, Brasil

\section{RESUMO}

Este ensaio analisa a produção e a conservação da masculinidade no romance O Ateneu (Raul Pompeia), que retrata a vida escolar em um internato de elite do século XIX. O ensaio discute principalmente a trajetória do menino Sérgio, narrador e protagonista do romance, que sofre experiências disciplinares destinadas a transformar suas marcas infantis e femininas em características adultas e masculinas. A produção e a conservação da masculinidade aparecem principalmente implicadas em eventos rituais que visam definir identidades conferindo marcas distintivas socialmente reconhecidas que tanto consagram a norma viril quanto estigmatizam e punem supostas fragilidades femininas ou comportamentos vistos como efeminados. A análise da produção e conservação da masculinidade em O Ateneu permite, assim, observar os "mecanismos históricos responsáveis pela desistoricização e eternização relativas das estruturas da divisão sexual" (Bourdieu, 2002, p. 8) atuantes naquele meio escolar.

PALAVRAS-CHAVE

O Ateneu; masculinidade; disciplina. 


\title{
SCHOOL PRODUCTION AND CONSERVATION OF MASCULINITY ON NOVEL O ATENEU
}

\begin{abstract}
This assay examines the production and conservation of masculinity in the novel O Ateneu (Raul Pompeia), which portrays the life in an elite boarding school on 19th Century. The assay mainly discusses about Sergio's trajectory, narrator and protagonist of the novel, which suffers disciplinary experiences to transform their infant and female brands into adult and males characteristics. The production and conservation of masculinity appear mainly involved in ritual events that aim to define identities giving socially recognized distinctive marks which acclaim the virile norm and stigmatize and punish presumed female frailties or behaviors seen as effeminate. The analysis of the production and conservation of masculinity in the OAteneu allows us to observe the "historical mechanisms responsible for the dehistoricization and perpetuation of structures related sexual division" (Bourdieu, 2002, p. 8) active in that school surrounding.

KEYWORDS

O Ateneu; masculinity; discipline.
\end{abstract}

\section{PRODUCCIÓN Y CONSERVACIÓN DE LA}

\section{MASCULINIDAD EN EL ROMANCE O ATENEU}

\section{RESUMEN}

El ensayo analiza la producción y conservación de la masculinidad en el romance $O$ Ateneu (Raul Pompeia) que retrata la vida escolar en un internado de elite del siglo XIX. El ensayo discute principalmente la trayectoria del niño Sérgio, narrador y protagonista del romance. Él sufre experiencias disciplinares destinadas a transformar sus marcas infantiles y femeninas en características adultas y masculinas. La producción y conservación de la masculinidad aparecen principalmente implicadas en eventos rituales que tenían por objetivo definir identidad asignando marcas distintivas socialmente reconocidas, que estipulaban la norma viril y estigmatizaban y castigaban supuestas fragilidades femeninas o comportamientos vistos como afeminados. $\mathrm{El}$ análisis de la producción y conservación de la masculinidad en O Ateneu permite, así, observar los "mecanismos históricos responsables de la ahistoricidad y eternización relativas de las estructuras de la división sexual" (Bourdieu, 2002, p. 8) actuantes en aquel medio escolar.

PALABRAS CLAVE

O Ateneu; romance; disciplina. 


\section{O internato! Destacada do aconchego placentário da dieta caseira vinha} próximo o momento de se definir a minha individualidade. Amarguei por antecipação o adeus às primeiras alegrias; olhei triste os meus brinquedos [...]. Mas um movimento animou-me, primeiro estimulo sério da vaidade: distanciava-me da comunhão da família, como um homem! ia por minha conta empenhar a luta dos merecimentos; e a confiança nas próprias forças sobrava.

Pompeia, 1993, p. 22

\section{INTRODUÇÃO}

Este ensaio tem por objetivo apresentar e discutir a construção escolar do modelo de homem no romance $O$ Ateneu com base nas passagens que tratam da questão da (in)definição sexual de meninos em um internato masculino de elite, na segunda metade do século XIX, no Rio de Janeiro. Essa discussão, no entanto, não se faz propriamente por intermédio das teorias dos estudos de gênero, embora o conhecimento já acumulado por esses trabalhos esteja, de maneira implícita, presente nas reflexões apresentadas. Assim, o ensaio dialoga de forma mais direta - no que concerne à discussão que contempla a construção social e histórica dos gêneros masculino e feminino - com a compreensão esboçada por Pierre Bourdieu em A dominação masculina (1999). Em contraposição, de forma associada, discute-se a questão da disciplina escolar tomando como base a obra Vigiar e punir, de Michel Foucault, de modo que se analise a produção e a conservação da masculinidade no contexto disciplinar do internato.

Este ensaio tem como base a dissertação de mestrado em educação que analisou os mecanismos disciplinares presentes no colégio Ateneu descrito no romance de Raul Pompeia. Na dissertação, a questão da produção e conservação da masculinidade não é tratada de forma particular, mas as sucessivas leituras do romance trouxeram o despertar para essa temática uma vez ela que se asseverou muito recorrente na obra.

$\mathrm{Na}$ elaboração do ensaio, levou-se em consideração o duplo percurso metodológico da análise sociológica da obra literária adotado por Bourdieu em As regras da arte (1996), na qual analisa $A$ educação sentimental, de Gustave Flaubert: a leitura externa (feita com base na estrutura do campo literário) e interna (feita com base na própria estrutura da obra). No entanto, a opção foi por uma leitura interna d'O Ateneu, ${ }^{1}$ considerando que a análise visou "construir sistemas de relações inteligíveis capazes de explicar os dados sensíveis" expressos no romance (Bourdieu, 1996, p. 14). Renunciando à análise das condições sociais que possibilitaram a escrita do romance e sendo este reduzido à condição de fragmento razoavelmente autônomo, procurou-se analisá-lo a partir dos "meios que lhe são próprios" (idem, p. 48).

1 Quer-se dizer que não serão exploradas as condições sociais do campo literário brasileiro do século XIX. 
Ao se adotar um olhar sociológico sobre a narrativa d'O Ateneu, é inevitável submeter paixões e interesses da fruição literária à critica movida pelo conhecimento científico. No entanto, se se renuncia à sacralidade da obra literária, pode-se falar de uma espécie de amor intellectualis rei ao romance, como uma "assimilação do objeto ao sujeito e imersão do sujeito no objeto, submissão ativa à necessidade singular do objeto literário (que, em mais de um caso, é ele próprio o produto de semelhante submissão)" (idem, p. 15). Essa reciprocidade é produto da construção do sistema formal operado pelo escritor que permite a compreensão do romance sem condicionar a interpretação interna da obra à sua "explicação" externa. Assim, embora o preço dessa análise seja "algo de profundamente desencantador" (idem), é ela que “[...] obriga a levantar com toda a clareza a questão da especificidade da expressão literária: dar forma é também seguir as formalidades, e a denegação operada pela expressão literária é o que permite a manifestação limitada de uma verdade que, dita de outra maneira, seria insuportável” (idem, p. 48).

A leitura realizada operou não pela mera repetição, mas pelo acúmulo das impressões sensíveis despertadas pelo texto e desdobradas em relações relativamente objetivas, possíveis em virtude da "realidade" inteligível criada pelo escritor por meio dos elementos que constituem a trama. Foi essa condição de realidade eufemizada - que permite falar do efeito de real que a literatura produz ao renunciar, sem dizer, a própria verdade que anuncia (idem) - que mobilizou a tentativa neste ensaio de analisar os mecanismos de produção e conservação da masculinidade no colégio Ateneu.

Um colégio, e mais particularmente um internato, é marcado pelo fato de ter sido socialmente instituído como lugar de rigoroso disciplinamento no processo ininterrupto de construção de si (Foucault, 1988), assim, no Ateneu se construía ou se cultivava tanto a inteligência quanto a masculinidade dos internos, pois aquela escola tinha por função educar os futuros membros da elite intelectual e política do período, isto é, "a fina flor da mocidade brasileira". ${ }^{2} \mathrm{O}$ colégio Ateneu, como lugar de desabrochamento daquela juventude, incitava os estudantes a uma transformação gradativa: de delicados e ensimesmados botões - porque até então protegidos à sombra materna e doméstica - a flores vultosas e dispostas aos riscos e bálsamos do universo das relações sociais e políticas.

A metáfora do desabrochamento que é relativa ao mundo da natureza e que remete ao significado do termo "cultura" (como ação de cultivar algo - uma planta, um espírito) fica evidente na passagem em que o autor descreve o menino Sérgio como "Criança educada exoticamente na estufa de carinho que é o regímen do amor doméstico". Aqui, a associação da criança a uma flor cultivada em "estufa" de carinho (a família) remete à origem do sentido figurado da educação de crianças como aquela que se exercia nos jardins de infância. E remete também à representação social que se tinha, naquela época, do período da vida denominado "infância", do indivíduo "criança" e, concomitantemente, de sua educação.

2 As frases ou palavras entre aspas duplas e não seguidas de referência foram todas retiradas do romance O Ateneu (Pompeia, 1993). 
Se, como sabemos, o processo de disciplinamento que rege as instituições da modernidade esteve plenamente disposto a sujeitar os corpos e os espíritos à normalização - como mostra a obra Vigiar e punir, de Michel Foucault -, sua função é a de promover a homogenia e, portanto, a elisão da diferença e do desvio. O Ateneu se apresenta, assim, como uma instituição em que atuam forças dispostas tanto a transformar corpo e espírito quanto aperfeiçoá-los ou colocá-los numa determinada direção, corrigindo possíveis rotas erráticas. Essas forças são principalmente disciplinares, característica comum das instituições escolares, mas também das instituições, entre outras, fabris, militares, penitenciárias, entre os séculos XVII e XIX (Foucault, 1975). Se o soldado, por exemplo, tornou-se, na segunda metade do século XVIII, algo que se fabrica ("de um corpo inapto, faz-se a máquina que se precisa" (idem, p. 137), também o aluno é fruto dessa descoberta do corpo como alvo do poder. A criança que o constitui é matéria considerada maleável e passível de aperfeiçoamento com vistas à produção de uma cidadania dócil, porém útil. Destinada à normalização, a criança em um internato é inserida numa rede de (re)conhecimentos classificados e classificatórios; isto é, de plena definição.

Assim, neste ensaio, vamos em particular focar a atenção naqueles momentos em que a disciplina, no colégio, visa à produção e conservação da virtude da virilidade, o virtus, enquanto dever ser e como forma socialmente honrada e desejável de um homem orientar-se (Bourdieu, 2002). Esse processo de masculinização, ou de aquisição de um habitus viril, que atinge tanto o corpo quanto o espírito dos meninos no Ateneu, imprime marcas que, opostas às características femininas, tornam reconhecível um homem diante de outro; ele é responsável, assim, em demarcar a masculinidade dos internos à medida que transforma seu estado indefinido ou ainda notadamente infantil-feminino, no qual os meninos geralmente se encontram quando recém-chegados à instituição. Isto é, o Ateneu tem por função transformar as crianças que tem sob sua guarda em homens e, assim sendo, apartá-las do universo da infância que se constitui pelas relações familiares e domésticas e pela presença da mulher-mãe.

Essa separação do universo da família e da infância é descrita por Raul Pompeia como a "definição" da "individualidade" do menino Sérgio, que então estava sendo destacado "do aconchego placentário da dieta caseira". Esse desenraizamento do universo feminino (a se manter a metáfora do cultivo de uma planta) é descrito pelo autor na forma de lamento do menino em dar "adeus" às suas "primeiras alegrias": os seus brinquedos.

O internato! Destacada do aconchego placentário da dieta caseira, vinha próximo o momento de se definir a minha individualidade. Amarguei por antecipação o adeus às primeiras alegrias; olhei triste os meus brinquedos, antigos já! os meus queridos pelotões de chumbo! [...] Força era deixar à ferrugem do abandono o elegante vapor da linha circular do lago, no jardim, onde talvez não mais tornasse a perturbar com a palpitação das rodas a sonolência morosa dos peixinhos rubros, dourados, argentados, pensativos à sombra dos tinhorões, na transparência adamantina da água [...]. (Pompeia, 1993, p. 22) 
Porém, na sequência, o menino relativiza a triste separação da família e dos brinquedos confortado por aquilo que chama de "primeiro estímulo sério da vaidade" e pela "confiança nas próprias forças". Assim, ele se distanciaria de seu mundo "como um homem!" e estaria pronto ("em armas") para a "conquista audaciosa do desconhecido" (a "casa de educação" que o deveria receber):

Mas um movimento animou-me, primeiro estímulo sério da vaidade: distanciava-me da comunhão da família, como um homem! Ia por minha conta empenhar a luta dos merecimentos; e a confiança nas próprias forças sobrava. Quando me disseram que estava a escolha feita da casa de educação que me devia receber, a notícia veio achar-me em armas para a conquista audaciosa do desconhecido. (idem, ibidem)

A aceitação do destino que se apresenta pressupõe a confiança do menino em suas forças diante da "luta dos merecimentos" e concebe, ao percurso a ser desbravado, uma dimensão épica, isto é, atribui à vida escolar que se inicia dimensões romanescas, porque plena de aventuras e superações. O sentimento de dever ser apresenta-se como estímulo dessa aventura e está incessantemente sujeito ao revigoramento ou consolidação do sentido socialmente compartilhado e atribuído à escola como instituição educativa.

Sérgio estará a partir de agora sujeito às forças do internato que tenderão a estruturar a sua subjetividade, inserindo-o em uma rotina escolar coordenada por princípios disciplinares que visam construí-lo como indivíduo, isto é, como homem. Assim, seu corpo será alvo de uma transformação e de uma formação que visam tanto a sua educação física quanto a sua educação moral. Essa educação, que será também intelectual, tem por fundamento e princípio a ordem escolar; uma ordem cujo sentido e validação, socialmente aceitos e compartilhados, são diariamente (re)instituídos no exercício dos ritos escolares, dos quais todos os agentes da instituição participam. Assim, os incitamentos à masculinidade no colégio fazem pressupor uma instituição na qual se produz e se conserva, por intermédio de ritos, formas sociais particulares dispostas tanto a consagrar quanto a estigmatizar e que, ao conferir marcas distintivas socialmente reconhecidas, definem, sobretudo, identidades. ${ }^{3}$

Nos ritos praticados no Ateneu observa-se uma crescente ênfase no abandono de práticas infantis por parte dos meninos (as brincadeiras e sua conotação afetiva), com a intenção de neles apagar os sinais da infância enquanto se constrói sua passagem para o mundo adulto. A trajetória escolar de Sérgio será marcada, assim, por cerimônias que visam à produção de uma "representação de si” orientada pelo princípio da masculinidade. Portanto, as características visivelmente frágeis no menino serão transformadas em robustas, e os sinais que nele porventura lembrem o universo infantil e/ou feminino serão transformados de modo a se adequarem à

3 Aqui se remete ao artigo no qual se esclarece a noção de ritos escolares com base no conceito antropológico de ritos de passagem que deu origem ao conceito de rites d'instituition de Pierre Bourdieu (Santos; Marchi, 2013a) 
representação do ideal masculino compartilhado no Ateneu e na sociedade da época. $\mathrm{O}$ internato procura, assim, produzir em seus internos um conjunto de valores que os adéquem a um sistema que lhes é, todavia, exterior (a "sociedade", o "mundo lá fora"). É por isso que o internato, que prepara ininterruptamente para a vida adulta (aquela que dá acesso às esferas de poder-economia, política, ciência), é visto como “instituição ideal do século XIX”(Ariès, 1981, p. 191). Lembremos que essas esferas da vida adulta são - por definição - não somente alheias ao universo infantil, mas naquela época também ao universo feminino.

A preparação, no Ateneu, para a vida adulta e disciplinada inclui, assim, os ritos como meios que procuram apagar, pouco a pouco, do corpo e da mente dos indivíduos as marcas da infância, da loucura, da delinquência, da feminilidade etc. (Foucault, 1975), isto é, de tudo aquilo que não é aceito em espaços e postos de prestígio e, correlativamente, de poder.

Neste ensaio, vamos tratar dos pequenos ritos e eventos do cotidiano escolar que produzem a passagem do menino Sérgio ou a transição que lhe é imposta, ao adentrar o Ateneu, entre a infância e aquilo que aos poucos se vai apresentar como sendo a vida adulta; ou seja, os eventos pelos quais o menino terá que passar para "fazer-se homem" no colégio (isto é, na vida).

Mas quem seria esse menino de 11 anos que "parece ter seis" e, portanto, ainda não "realmente desenvolvido", levado pelas mãos do pai "à porta do Ateneu"? Quem é o garoto que faz a "estreia das calças longas" e que, retirado do "aconchego da dieta caseira", é "perfeitamente virgem" às sensações de um universo ainda desconhecido?

Sérgio é uma criança que está prestes a ser iniciada, no âmbito do universo escolar, ao que Perrenoud (1995) chama de "ofício de aluno". No regime de internato, pode-se considerar que essa iniciação pressupõe, doravante, um exercício constante de enquadramento disciplinar. Portanto não é sem dificuldades e tristezas que o menino é levado a deixar o universo de uma infância burguesa para se construir no mundo adulto. Uma tristeza que é partilhada pelos membros do seu universo doméstico, pois a mãe beija, na despedida, a testa do menino e molha "de lágrimas os [seus] cabelos". Para o menino, separar-se dos privilégios que a infância em família lhe oferece, tais como de seus queridos brinquedos, é, como vimos, dar "adeus às primeiras alegrias" dos jogos da infância para dar início a um jogo de homens, como demonstra o conselho que recebe de um experiente (porque veterano) colega de internato: "faça-se forte aqui, faça-se homem".

Todos os rituais de instituição da disciplina e da virilidade, alicerçados na violência simbólica (Bourdieu, 1999) em que repousam as práticas escolares, introduzem pouco a pouco a criança do romance aos princípios da construção de homens no Ateneu. Ao adentrar o colégio, Sérgio terá que vestir calças e "há de ter a bondade de ir ao cabeleireiro" para "deitar fora" seus "cachinhos". Essa solicitação - "salgada de censura" - é feita pelo diretor do Ateneu (Aristarco), o "grande educador" de "peito largo", núcleo do poder pedagógico, moral e disciplinar da época retratada no romance: 


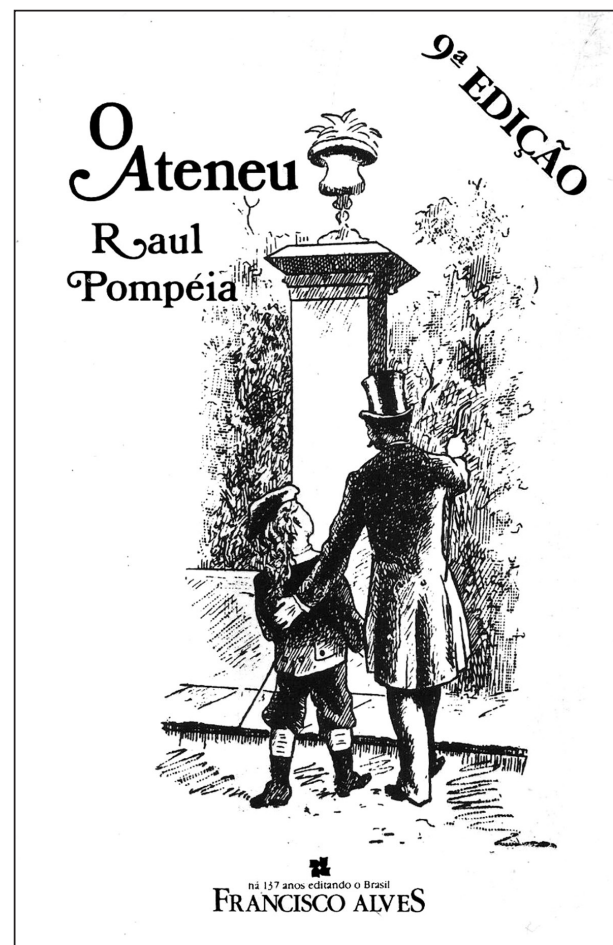

Figura 1 - Sérgio sendo levado pelo pai ao colégio Ateneu.

Fonte: Pompeia (1993, capa).

- Como se chama o amiguinho? - perguntou-me o diretor.

- Sérgio... - dei o nome todo, baixando os olhos e sem esquecer o "seu criado" da estrita cortesia.

- Pois, meu caro Sr. Sérgio, o amigo há de ter a bondade de ir ao cabeleireiro deitar fora estes cachinhos... ${ }^{4} \mathrm{Eu}$ tinha ainda os cabelos compridos, por um capricho amoroso de minha mãe. $\mathrm{O}$ conselho era visivelmente salgado de censura. $\mathrm{O}$ diretor, explicando a meu pai, acrescentou com o risinho nasal que sabia fazer: "Sim, senhor, os meninos bonitos não provam bem no meu colégio [...]" (Pompeia, 1993, p. 32)

4 O processo de disciplinamento escolar, como disserta Comenius (1997 [1627]) em obra seminal da pedagogia moderna, é um constante serviço de "poda". A metáfora da educação como cultivo de uma planta, mencionado anteriormente, tem certamente origem nessa obra. A atitude do diretor do Ateneu - Aristarco - é, portanto, homóloga à do jardineiro que evita que as plantas se desenvolvam de forma selvagem ou desordenada, prejudicando o desenvolvimento de outras plantas. 
Nem um pouco tácito, esse anúncio de circuncisão simbólica, ou seja, a solicitação do corte da "infância que aí fica, nos cabelos louros", e que deixará o menino com a "sensação de nudez à nuca", produz os efeitos dos ritos de passagem que inscrevem no corpo das crianças a mudança para o mundo adulto. Esses ritos marcam tanto física quanto simbolicamente a nova condição em que a criança se encontra, fazendo imperar um dever ser sobre a sua conduta.

Assim, o corte dos cabelos do menino significa também a excisão dos vestígios de feminilidade/infantilidade de um corpo que, pertencendo agora ao universo dos rapazes, deve participar da homogeneidade das formas. Aqui se pode sugerir que a retirada, em Sérgio, dos vestígios do que é (ainda) infantil e/ou feminino, e que nele imprime o modelo masculino da aparência e a constituição do "ser homem" no Ateneu, tem uma (dupla) função: impedir tanto a indefinição sexual (ou de gênero) que normalmente acompanha a primeira infância, quanto reprimir a conduta e o desejo homossexual (no colégio fortemente censurados).

Os ritos de instituição inscrevem uma série de diferenciaçôes, visando destacar em cada agente - homem ou mulher - signos exteriores conforme sua distinção ou gênero sexual (socialmente definidos), assim como estimular práticas que convêm a cada sexo, desencorajando e proibindo outras: "É, por exemplo, o caso dos ritos 'de separação', que têm por função emancipar um menino com relação à sua mãe e garantir sua progressiva masculinização, incitando-o e preparando-o para enfrentar o mundo exterior" (Bourdieu, 1999, p. 35).

Bourdieu (1980) entende que a ordem, longe de poder ser considerada força unilateral, nasce antes do compartilhamento de determinados princípios. $\mathrm{Na}$ forma de disciplina, o babitus se expressa, portanto, como "princípios geradores e organizadores de práticas e de representações" (idem, p. 88). Assim, o processo de construção do habitus naturaliza e suspende a construção social entre masculino/ feminino, entre infância/idade adulta, entre ordem/desordem, entre dentro/fora, entre internato/escola/mundo, suspendendo interrogações que possam ameaçar essas rígidas separações.

A análise da produção e conservação da masculinidade no Ateneu há de permitir observar os "mecanismos históricos responsáveis pela desistoricização e eternização relativas das estruturas da divisão sexual" atuantes no âmbito escolar ${ }^{5}$ (Bourdieu, 2002, p. 8). Por isso é que tomamos aqui o caso particular da descrição romanesca de um colégio interno exclusivamente para rapazes do século XIX como representativo, em sua forma histórica, dessa divisão.

\section{"OLHE; UM CONSELHO: FAÇA-SE FORTE AQUI, FAÇA-SE HOMEM"}

Sérgio, como calouro no internato e, portanto,"perfeitamente virgem para as sensações novas da nova fase" que o Ateneu representa, está sujeito às experiências conflituosas e imprevisíveis à medida que desconhece os imperativos das condutas

5 As citações diretas da edição francesa de $A$ dominação masculina são de tradução livre dos autores. 
aprovadas no colégio. Assim, o menino é, pela primeira vez, orientado sobre a conduta masculina a ser mantida no colégio pelo aluno veterano que the foi recomendado: o "honroso Rebelo", o "mais velho" e "mais sério" da turma, que na "hora de descanso" passeava com Sérgio lhe transmitindo conselhos.

É de Rebelo o contundente aviso: "faça-se forte aqui, faça-se homem. Os fracos perdem-se". O conselho foi dado ao novato na primeira semana de aula, diante das provocações de que era alvo no pátio do colégio. Além disso, o aluno mais velho explana ao menino como está organizado ou classificado o comportamento do contingente escolar: embora aquela fosse uma escola só de rapazes, no Ateneu poderia ser encontrado, de acordo com Rebelo, "dous sexos, como se fosse uma escola mista". Essa advertência é explicitada por meio das ideias de "sexo fraco" (com referência às características femininas) e "sexo forte", sendo que a primeira aponta os meninos "tímidos, ingênuos, sem sangue" e que mais parecem - de forma "pervertida" - "meninas ao desamparo". Assim, o conselho do veterano Rebelo destina-se essencialmente a fazer Sérgio compreender que deve dispensar protetores, ou seja, dispensar a ajuda de alunos mais experientes que the podem oferecer afetuosa proteção em troca de submissão, esta vista como virtude negativa associada ao comportamento feminino:

Os gênios fazem aqui dous sexos, como se fosse uma escola mista. Os rapazes tímidos, ingênuos, sem sangue, são brandamente impelidos para o sexo da fraqueza; são dominados, festejados, pervertidos como meninas ao desamparo. Quando, em segredo dos pais, pensam que o colégio é a melhor das vidas, com o acolhimento dos mais velhos, entre brejeiro e afetuoso, estão perdidos... Faça-se homem, meu amigo! Comece por não admitir protetores. (Pompeia, 1993, p. 44)

O sistema classificatório no Ateneu rotula os internos que expressam propriedades destoantes do padrão de virilidade e honradez estabelecido, sendo vistas como infantis e/ou femininas, e por isso como pertencendo ao "sexo da fraqueza" e representando, naquele sistema, os condenados às violações. Essas propriedades são rejeitadas à medida que se expressam como características inadmissíveis num "universo de homens". Elas expressam igualmente uma ameaça à ordem simbólica da instituição, na possibilidade de se apresentarem também como manifestos de resistência.

$\mathrm{O}$ caráter negativo atribuído à necessidade de protetores no colégio indica que "ser protegido" significa assumir a condição feminina; assim, os meninos recém-chegados e ainda não dominando os códigos locais de comportamento instituídos, tanto formal quanto informalmente, devem fazer-se fortes diante das prováveis investidas de companheiros mais velhos e "mal-intencionados". A condição de novato no internato representa uma condição de vulnerabilidade também pela carência de se ter por perto alguém mais experiente que o proteja "dos vexames da vida colegial dos pequenos".

Assim, Sérgio narra suas aventuras e desventuras diante do novo mundo que se lhe apresenta no Ateneu, denotando, de acordo com Proença (2011, p. 17), o engajamento de Pompeia "na destruição de mitos de toda uma viciosa instituição". 


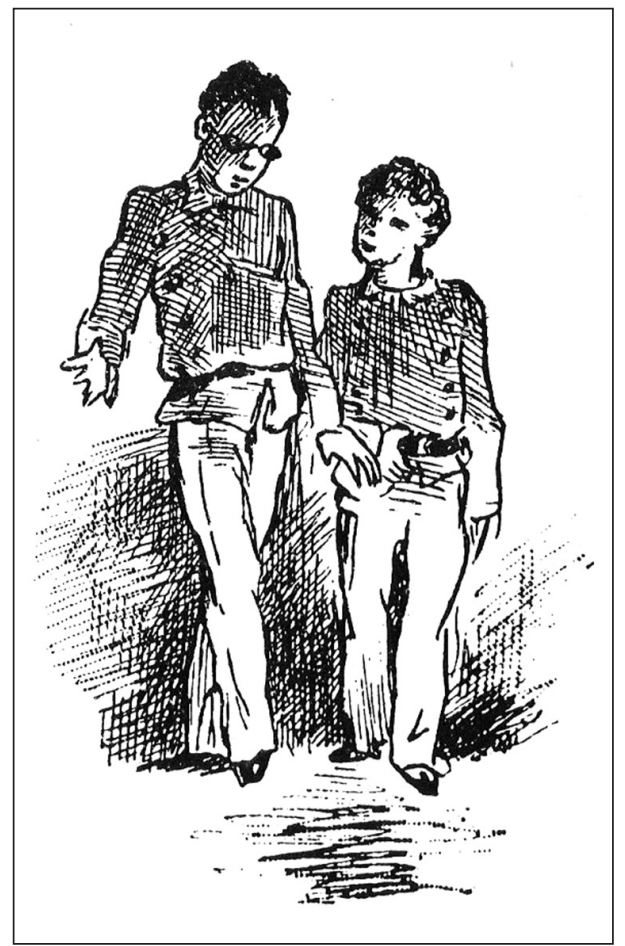

Figura 2 - Rebelo aconselha Sérgio enquanto passeiam.

Fonte: Pompeia (1993, p. 45).

Essa denúncia social ou crítica amarga à escola, como sugere Proença (idem, p. 18), pode ser percebida pelo "niilismo com que [Pompeia] envolve os personagens, quase todos retratados de maneira a mais depreciativa”. Assim, Rebelo, o veterano, previne Sérgio em relação aos colegas de internato: "Uma cáfila! Não imagina, meu caro Sérgio. Conte como uma desgraça ter que viver com esta gente”. E prossegue:

Aí vão as carinhas sonsas, generosa mocidade... Uns perversos! Têm mais pecados na consciência que um confessor no ouvido; uma mentira em cada dente, um vício em cada polegada de pele. [...] São servis, traidores, brutais, adulões. Vão juntos. Pensa-se que são amigos... Sócios de bandalheira! Fuja deles, fuja deles. Cheiram à corrupção, empestam de longe. Corja de hipócritas! Imorais! (Pompeia, 1993, p. 43)

A essa descrição depreciativa dos agentes do internato não escapam, certamente, os adultos, mas é em um universo de adolescentes "já marcados por uma hipocrisia e maldades próprias de adultos" que vamos focar nossa análise e, mais especialmente, nos "afeminados, ou quase, [que] constituem verdadeira galeria, a que não escapa nem o herói, seja através de insinuações do autor, seja ostensivamente" (Proença, 2011, p. 18). 
Destacamos, no entanto, que - a nosso ver - a questão da efeminação surge na narrativa do menino Sérgio não como condenação moral de comportamento reprovável e reprovado em um universo de homens, e sim como condição possível em um "período de constituição moral". Assim, o menino percebe nos demais companheiros, como em si mesmo, a luta travada na constituição de si. $\mathrm{O}$ modelo perseguido no colégio é o de homens fortes, seguros, inteligentes, sem quaisquer resquícios de dúvidas ou fraquezas tanto no que diz respeito à sexualidade quanto no que se refere à correta conduta de estudante/aluno.

São muitas as passagens nas quais o autor descreve os alunos do internato como possuidores de características (físicas ou comportamentais) de "efeminação" e não há possibilidade de expormos todas aqui; porém, uma passagem na qual o menino Sérgio descreve seus colegas de classe basta para ilustrar esse conjunto: "eram cerca de vinte; uma variedade de tipos que me divertia","o Almeidinha, claro, translúcido, rosto de menina [...] com um vagar lânguido"; "o Cândido [...] com modos de mulher, aquele arzinho de quem saiu da cama, com preguiça nos olhos"; "o Ribas [...] primeira voz do Orfeão, uma vozinha de moça", "cantava as orações com a doçura feminina de uma virgem".

Há também muitas passagens relativas ao protagonista Sérgio nas quais transparece a ambiguidade sexual entre os pares no colégio. Um exemplo é a relação de Sérgio com outro aluno veterano, Sanches, que, assim como Rebelo, também lhe foi "recomendado" pelos professores. Note-se que essa "recomendação" era feita aos meninos novatos no intuito de que mantivessem estreita relação acadêmica com estudantes mais velhos que lhes poderiam servir de monitores (ou explicadores) nos estudos.

Assim, a proteção despendida pelos veteranos em relação aos novatos n'O Ateneu, exercida na forma de violência simbólica, comportava igualmente um viés de fragilização que correspondia, por isso, à infantilização, à feminilização e à desmasculinização. $\mathrm{O}$ sistema disciplinar instalado no colégio objetivava impedir os trabalhos de fragilização que silenciosamente representavam possíveis pequenos atentados à ordem. Os calouros são aqueles mais sujeitos a participarem dessas pequenas contravenções porque geralmente não dispõem ainda da disciplina incorporada que se expressa no senso prático (Bourdieu, 1980) e que orienta as condutas legitimadas em tal sistema.

Ao ser recomendado a Sanches, Sérgio de imediato o considerou "supinamente antipático: cara extensa, olhos rasos, mortos, de um pardo transparente, lábios úmidos, porejando baba, meiguice viscosa de crápula antigo". Embora Sanches fosse "o primeiro da classe, muito inteligente", de acordo com Sérgio, ainda que ele fosse o primeiro "do coro dos anjos", era em seu conceito "a derradeira das criaturas". Fica evidente a antipatia e mesmo a repulsa que o veterano causou já de início ao menino, que, no entanto, suportava a presença do aluno diante dos préstimos que este lhe concederia relativamente ao aproveitamento dos estudos.

O caráter protetor de Sanches, extrapolado ao ponto da "pegajosa ternura", incomoda o menino Sérgio até o dia em que aquele o salva de um afogamento na piscina do colégio, situação que depois o menino desconfia ter sido forjada por seu "salvador" de modo que pudesse obter sua gratidão e confiança. 
Um grande tomou-me ao ombro e me depôs à borda, estendido, vomitando água. Levei algum tempo para me inteirar do que ocorrera. Esfreguei por fim os olhos e verifiquei que o Sanches me tinha salvo. "Ia afogar-se!" disse ele, amparando-me a cabeça enquanto me desempastava os cabelos de cima dos olhos. (Pompeia, 1993, p. 52).

A partir desse dia, o menino se vê cada vez mais assediado pela constante presença protetora de Sanches que,

[...] como os mal-intencionados, fugia dos lugares concorridos. Gostava de vaguear comigo, à noite, antes da ceia, cruzando cem vezes o pátio de pouca luz, cingindo-me nervosamente, estreitamente até levantar-me do chão. Eu aturava, imaginando em resignado silêncio o sexo artificial da fraqueza que definira Rebelo. (idem, p. 60)

Assim, tendo que manifestar sua gratidão, Sérgio passou a dissimular a "repugnância de gosma" aceitando a "íntima amizade" que o colega lhe requeria. Além disso, estando já "iniciado na convivência íntima da escola” como um "encarcerado em seu cárcere", premido pela "força das coisas" e "descrente da fraternidade do colégio", sentiu-se um "menino acovardado" a ponto de dispensar a "lição viril de Rebelo: prescindir de protetores" e passou a desejar "um protetor, alguém que me valesse, naquele meio hostil e desconhecido". É assim que Sérgio confessa notar que, pouco a pouco, the ia invadindo aquilo que o bom Rebelo havia previsto: "a efeminação mórbida das escolas”.

E, como se a alma das crianças, à maneira do físico, esperasse realmente pelos dias para caracterizar em definitivo a conformação sexual do indivíduo, sentia-me possuído de certa necessidade preguiçosa de amparo, volúpia de fraqueza em rigor impróprio do caráter masculino. (idem, p. 54)

Essa "fraqueza de caráter" ou "desmantelo de energia" sentidos pelo menino foi o que permitiu a aproximação mais cerrada e constante de Sanches - como um "possuidor forte"-; aproximação sempre dissimulada à vista de um inspetor e que, portanto, serviu também de "alarme" a Sérgio.

Estimulado pelo abandono que lhe parecia assentimento tácito, Sanches precipitou um desenlace [aproveitando estar a sós com Sérgio em local ermo e escuro] [...] sem transição o companheiro chegou-me a boca ao rosto e falou baixinho.

Só a voz, o simples som covarde da voz, rastejante, colante, como se cada sílaba fosse uma lenda, horripilou-me, feito o contato de um suplício imundo. Fingi não ter ouvido; mas houve intimamente a explosão de todo o meu asco por semelhante indivíduo. (idem, p. 60-61)

Desse modo, Sérgio comprovou sua repugnância instintiva inicial pelo colega e, após o incidente, em um "rasgo de heroicidade”, rompeu de uma só vez com “o 
amigo, o explicador e o vigilante", que ao perceber que "estava tudo acabado" passou a rondar Sérgio "temperando o olhar com o brilho de facadas". Esse desfecho provou ser dramático para o aproveitamento escolar do garoto que, agora perseguido pelo antigo amigo, decidiu "escandalizar o mundo com uma vadiação sem exemplo!" conduzindo-se a uma "amarga descida ao fundo descrédito escolar".

Se esse episódio de assédio indesejado teve más consequências para a trajetória escolar de Sérgio, a relação travada pelo menino com Bento Alves, bibliotecário do grêmio estudantil Amor ao saber, é descrita no romance como saudosa amizade que, embora assim definida, não estava livre de ambiguidade sexual, como denota o seguinte trecho:

A amizade do Bento Alves por mim e a que nutri por ele me faz pensar que, mesmo sem o caráter de abatimento que tanto indignava ao Rebelo, certa efeminação pode existir como um período de constituição moral. (idem, p. 107)

É assim que Sérgio afirma ter "estimado femininamente" o amigo, "porque era grande, forte, bravo", e porque ele lhe "podia valer" em sua amizade fraterna, tímida e platônica:

Para me fitar, esperava que eu tirasse dele os meus olhos. [...] eu via de longe o amigo, atento, seguindo-me o seu olhar como um cão de guarda. Soube depois que ameaçava torcer o pescoço a quem pensasse apenas em me ofender; seu irmão adotivo! (idem, ibidem)

Assim, o amigo "sabia ser [...] fraternal, paternal, quase digo amante, tanta era a minudência dos seus cuidados". Vemos que nessa narrativa Pompeia não se priva de ironizar a relação, colocando sobre ela a ambiguidade que não passava despercebida aos demais internos e não escapava, portanto, à "escorraçada maledicência". Essa chegou a ponto de causar um "duelo" entre Bento Alves e outro menino que perguntara sobre a data do "casamento", solicitando "convite para as bodas".

Sérgio aceita de bom grado a amizade e a proteção oferecidas e, mesmo tendo já assumido entre os internos "um belo ar de impávida altania", confessa sentir-se bem "na submissão voluntária, como se fosse artificial a bravura, à maneira da conhecida petulância feminina". A ironia do autor em relação à ambígua amizade entre dois rapazes "no movimento geral da existência do internato" novamente se evidencia na passagem em que Sérgio admite assumir seu "papelzinho de namorada faz de conta" e de levar a sério as cenas correspondentes, ocupando-se: "com o laço da gravata dele, com a mecha de cabelo que lhe fazia cócegas aos olhos, [soprando-lhe] ao ouvido segredos indistintos para vê-lo rir". As atitudes do "bom amigo", no entanto, chegaram "ao excesso das flores" que enviava escondidas dentro de livros. As pétalas do princípio viraram "a imprudência de um ramalhete", e é assim que o menino se pergunta, diante de tamanha manifestação de afeto: "Que devia fazer uma namorada?"

Porém, assim como ocorrera com a indesejada amizade de Sanches, a amizade por Bento Alves tem também desfecho abrupto: certo dia, relata o protagonista, o querido amigo simplesmente lhe caiu em cima e, após luta feroz, Bento Alves deixa 
o colégio. $\mathrm{O}$ que teria acontecido para que a amizade tão forte e idílica terminasse de forma assim violenta e definitiva nem mesmo o protagonista parece saber e tampouco o autor nos dá qualquer pista para que se compreenda o fato. Assim, ficamos os leitores a imaginar que, talvez a maledicência dos outros meninos, antes mencionada, possa ter causado tamanha reação de Bento Alves.

Há por fim, também no romance, o relato da intensa amizade de Sérgio por Egbert, que merecia “ternuras de irmão mais velho" e, no entanto, as passagens que descrevem essa amizade lembram o enlevo e a adoração que cerca nos romances os casais apaixonados:

Vizinhos ao dormitório, eu, deitado, esperava que ele dormisse para vê-lo dormir e acordava mais cedo para vê-lo acordar. Tudo que nos pertencia era comum. Eu por mim positivamente adorava-o e o julgava perfeito. [...] admirava-o, desde o coração, até a cor da pele e à correção das formas. [...] No recreio, éramos inseparáveis, complementares, como duas condições recíprocas de existência. [...] Amor unus erat. [...] Sentávamo-nos à relva. Eu descansando a cabeça aos joelhos dele, ou ele nos meus. (idem, ibidem)

A amizade de Sérgio por Bento Alves e Egbert, por mais que contenha relatos que denotam a ambiguidade sexual da paixão e o devotamento de uma amizade entre adolescentes, também contém exatamente tudo o que existe de mais propriamente humano no relacionamento entre duas pessoas que, à parte a rígida divisão entre o comportamento socialmente aceitável e definido para os sexos, são levadas - em um regime de clausura - a viver de forma muito próxima e, nessa convivência, compartilhar situações e momentos que caracterizam o início da puberdade (o considerado "hiato" entre a infância e a vida propriamente adulta). Assim é que os relatos são também entremeados com descrições do mais claro deleite intelectual, da pura e simples contemplação - a dois - da natureza, das alegrias compartilhadas em um brinquedo ou numa gazetilha, das cumplicidades e vicissitudes, enfim, que compõem a vida escolar em um internato. Assim, se não fosse, talvez, nossa distância no tempo (já que a história que passa no século XIX), não haveria tanto a estranhar na forma como Raul Pompeia descreve as relações de afeto entre colegas (do mesmo sexo) no colégio, afinal "o advento da oposição entre homossexuais e heterossexuais é algo muito recente, e foi sem dúvida só após a Segunda Guerra Mundial que a heterossexualidade ou a homossexualidade se impôs como uma escolha exclusiva" (Bourdieu, 2002, p. 117).

O que, no entanto, parece permanecer como invariável até aqui (e também no romance), da definição da homossexualidade, é a assunção da (presumida, porque socialmente construída) passividade feminina, sempre evocada pelo menino Sérgio em suas recordações. Assim, ou por compartilhar, ratificando, a construção social do que Bourdieu (1999, p. 102) define como as "invariantes trans-históricas da relação entre os 'gêneros"' (isto é, os papéis ativo/passivo atribuídos respectivamente a homens e mulheres), ou "o trabalho constante de diferenciação a que homens e mulheres não cessam de estar submetidos e que os leva a distinguir-se masculinizando-se ou feminilizando-se" (idem, ibidem), ou, quem sabe, por desejar fazer ver (de forma 
socialmente crítica) essa convenção ou arbitrário social, Raul Pompeia tenha colocado nas palavras de seu protagonista aquilo que socialmente está definido, mas que merece reflexão. Aqui, pode-se mais uma vez ${ }^{6}$ evocar a prerrogativa da obra literária (colocada em evidência por Bourdieu em seu trabalho de dessacralização da obra de arte): tomada como objeto de estudo sociológico, a literatura pode, por vezes, dizer mais sobre o mundo social que muitos escritos com pretensão científica (Bourdieu, 1996, p. 48). Isso porque:

O "efeito de real" é essa forma muito particular de crença que a ficção literária produz através de uma referência denegada ao real designado que permite saber recusando saber o que ele é realmente. A leitura sociológica rompe o encanto. Colocando em suspenso a cumplicidade que une o autor e o leitor na mesma relação de denegação da realidade expressa pelo texto, ela revela a verdade que o texto enuncia, mas de modo tal que não a diz; além disso, ela faz surgir a contrário a verdade do próprio texto que, precisamente, define-se em sua especificidade pelo fato de que não diz o que diz como ela o diz. (idem, ibidem)

Se as passagens selecionadas neste item exprimem, de certa maneira, relacionamentos que beiram o limite entre a amizade e o assédio sexual ou entre a amizade e o amor homossexual, caracterizando assim relacionamentos que sabemos ser, de certo modo, comuns e tolerados em locais que reúnem durante muito tempo e em regime fechado pessoas do mesmo sexo (como internatos ou prisões), o episódio relatado a seguir caracteriza, no entanto, aquilo que no Ateneu era implacavelmente vetado e, portanto, punido: o comportamento assumidamente efeminado. Isso porque, agindo na ignomínia de uma "contranatureza", ele combatia em dupla frente a ordem a ser (re)produzida no colégio: a natureza presumida e essencialmente masculina, viril - que é a de todo homem - e a ordem que regia a disciplina no colégio.

\section{ANOMALIA E PERDIÇÃO: “UMA CARTA DO CÂNDIDO, ASSINADA CÂNDIDA"}

O comportamento relativo à produção e conservação da masculinidade/feminilidade está geralmente implícito na ordem das coisas admitidas como naturais, e a transgressão ocasionada pela não correspondência aos ideais de conduta socialmente aceitáveis ou prescritos expressa a confiança atribuída à invulnerabilidade dessa ordem. A passagem a seguir descreve o ritual de punição pública que especificamente dois estudantes sofreram no Ateneu em virtude de terem sido flagrados em correspondência íntima que marcava um encontro romântico no jardim do colégio.

À hora da ceia, na mesma porta em que se lia a gazetilha das aulas, sombrio como nunca, vagaroso como os compassos de réquiem, tétrico como o juízo fi-

6 Este ensaio tem como antecedentes três outros artigos já publicados (Santos; Marchi, 2013a, 2013b, 2013c). 
nal, entrou o diretor. [...] "Tenho a alma triste. Senhores! A imoralidade entrou nesta casa! Recusei-me a dar crédito, rendi-me à evidência..." Com todo o vigor tenebroso dos quadros trágicos, historiou-nos uma aventura brejeira. Uma carta cômica e um encontro marcado no Jardim. "Ah! mas nada me escapa... tenho cem olhos. Se são capazes, iludam-me! Está em meu poder um papel, monstruoso corpo de delito! assinado por um nome de mulher! Há mulheres no Ateneu, meus senhores!" Era uma carta do Cândido, assinada Cândida. (Pompeia, 1993, p. 148)

E o diretor do colégio prossegue afirmando a suprema ignomínia (a de um homem se fazer passar por mulher): "Essa mulher, essa cortesã fala-nos da segurança do bosque, da solidão a dois... um poema de pouca vergonha!"

O sistema de vigilância no colégio - o diretor tem "cem olhos"-, se não pode inibir a transgressão, captura os transgressores e o rito de nomeação dos infratores os lança sob o feixe de luz da visibilidade pública, degradando-os à medida que os torna nomeadamente representantes dos valores deplorados no colégio. O rito também destaca a ausência da norma incorporada em um espaço predominantemente normativo, ampliando os sentidos dos alarmes, da marginalidade e da danação. $\mathrm{O}$ rito da punição exerce, então, exibição intensificada da anomalia e da perdição que a acompanha. Aristarco, a principal figura masculina do internato, lidera o exercício da justa punição:

[...] Amanhã é o dia da justiça! [...] tenho a lista dos comprometidos... e quem negar espontâneo auxílio ao procedimento da justiça, será reputado cúmplice e como tal: punido! (idem, ibidem)

Confessa o protagonista que "A devassa prometida fazia alarma geral", pois "ninguém havia que não estivesse implicado na comédia colegial dos sexos, ao menos pelo enredo remoto do ouvi dizer".

O exercício da justiça corresponde ao sistema disciplinar no colégio, aquele que define o inaceitável - a existência de "mulheres no Ateneu". ${ }^{7}$ E esse exercício ritualizado da justiça implica ser socialmente compartilhado à medida que vela "a verdade da usurpação", ou o arbitrário inaugural, que "sem razão se tornou razoável” (Pascal, 1962, p. 52), autêntico e eterno. Os ritos são possivelmente práticas que concentram e expressam mais intensamente os sentidos institucionalmente compartilhados e autenticados na forma de contrato implícito. $\mathrm{O}$ desempenho pleno dos ritos depende da concordância entre os agentes envolvidos que conferem crença na necessidade do cumprimento dos procedimentos ritualísticos. "À hora do primeiro almoço, como prometera, Aristarco mostrou-se em toda a grandeza fúnebre dos justiçadores":

7 Note-se que o diretor não leva em conta a presença real de três mulheres no ambiente (sua esposa, Ema, sua filha, Melica, e a camareira, Ângela), o que reforça a ideia da invisibilidade das mulheres no colégio (reflexo da posição desse grupo na sociedade), tema que será desenvolvido no próximo item. 


\section{"Levante-se, Sr. Cândido Lima!"}

"Apresento-lhes, meus senhores, a Sra. D. Cândida", acrescentou com uma ironia desanimada.

"Para o meio da casa! E curve-se diante dos seus colegas!"

Cândido era um grande menino, beiçudo, louro, de olhos verdes e maneiras difíceis de indolência e enfado. Atravessou devagar a sala, dobrando a cabeça, cobrindo o rosto com a manga, castigado pela curiosidade pública.

"Levante-se, Sr. Emílio Tourinho... Este é o cúmplice, meus senhores!"

[...] [Tourinho] Nada absolutamente conformado para galã; mas era com efeito

o amante. "Venha ajoelhar-se com o companheiro". (Pompeia, 1993, p. 150)

O caráter performático do rito atua na disseminação do arbitrário que divide sexualmente os agentes. $\mathrm{O}$ arbitrário disseminado e compartilhado pressupõe apropriação e reprodução, portanto, ponto comum de reconhecimento cognitivo entre os participantes do rito. A "pior humilhação para um homem consiste em ser transformado em mulher" (Bourdieu, 2002, p. 38). O exercício autorizado da humilhação - porque exercido sob a égide da justiça - suspende as resistências do homem para esvaziá-lo sequestrando sua masculinidade enquanto a denuncia como socialmente perdida.

A conformidade com o sistema classificatório estabelecido resulta em lucros simbólicos, como o reconhecimento entre semelhantes, que por sua vez garante a validade desse sistema. O respeito que Cândido e Tourinho, cúmplices no crime de homossexualismo, devem expressar - ajoelhando-se diante dos erguidos - formaliza o ajustamento às posições homólogas ao curvado/reto, baixo/alto, feminino/masculino etc. Os agentes punidos são impelidos às posições marginais que sinalizam distanciamento dos valores predominantemente masculinos e disciplinares, sujeitos senão ao exílio simbólico - exemplo: ser vergonhosamente reduzido a nada - ao menos às tentativas de (re)ajustamento institucional expressas nos trabalhos de punição:

Conduzidos pelos inspetores, saíram os doze como uma leva de convictos para o gabinete do diretor, onde deviam ser literalmente seviciados, segundo a praxe da justiça do arbítrio. Consta que houve mesmo pancada de rijo. (Pompeia, 1993, p. 151)

O consenso a respeito das formas de condutas legitimadas no colégio - com o lucro da convicção compartilhada - intensifica os vexames públicos derivados das punições, que por sua vez são apreciados ou compreendidos pelo sistema classificatório incorporado nas formas antagônicas e duais de honra/vergonha, forte/fraco, firme/sentimental etc. Assim, de acordo com Bourdieu (1999), como a honra, a vergonha (seu reverso) - diferentemente da culpa - é experimentada diante dos outros e, por isso, a virilidade tem que ser validada pelos pares e atestada pelo reconhecimento de fazer parte de um grupo de "verdadeiros homens". Assim é que "Inúmeros ritos de instituição, sobretudo os escolares ou militares, comportam verdadeiras provas de virilidade, orientadas no sentido de reforçar solidariedades viris" (Bourdieu, 1999, p. 65). 
O sentimento que faz "a sala inteira" respirar aliviada após a cerimônia da punição realizada no Ateneu expressa o conforto da salvação coletiva daqueles que não tiveram os nomes expostos e que mantiveram afirmada sua identidade de homens e sua conformidade à ordem simbólica e prática do colégio.

\section{OS MEATOS DE PASSAGEM - O FEMININO}

No internato, "escola terrível do realismo social, onde tudo desde cedo está presente, o oportunismo, o servilismo interesseiro, a delação, a traição, a denunciação", ocorrem também relações "que podemos dizer encantadas" (Bourdieu, 2001, p. 214) e que marcam a ambiguidade e a complexidade da instituição escolar, espaço notadamente heterogêneo com propósitos homogenizadores. A forma feminina que aparece personificada em D. Ema (esposa do diretor do colégio) e Ângela (a empregada espanhola) exerce tensões em relação ao ideário masculino conservado no colégio. Essas personagens, no entanto, intervêm de forma tácita, desatenta e desinteressada, ou seja, longe de minarem progressivamente a ordem simbólica do Ateneu, elas servem antes como reforço da norma pela oposição que significam.

Ambas jovens e belas, as personagens são opostas também entre si, em sua própria natureza de mulher: do ponto de vista moral, D. Ema é a mãe, a cuidadora (no desempenho da função de enfermeira do colégio), esposa dedicada e discreta, cuja presença serve para, em contraste, dar brilho à imponente figura do marido e diretor do colégio. Há de se notar, no entanto, que ela é também representada no romance como figura possivelmente transgressora, pois sobre D. Ema pairavam, apesar de toda a distinção, boatos a respeito de sua fidelidade. Já Ângela, a doméstica, personifica as mulheres de classe inferior que, também por sua condição de migrante, desempenha funções socialmente desvalorizadas e essencialmente femininas: o serviço de casa (lavar, limpar, arrumar). Além disso, Ângela (ao contrário de D. Ema, que reúne em torno de si desejos velados e culposos) apresenta-se abertamente como objeto de desejo por parte dos agentes do colégio.

D. Ema e Ângela ocupam posições razoavelmente indefinidas no colégio porque são posições não contempladas na hierarquia ou estrutura escolar estando sujeitas, pelo fato de serem do sexo oposto, ou seja, as únicas mulheres presentes no ambiente do Ateneu, às impressões sentimentais e erotizantes de seus habitantes. ${ }^{8}$ Essa indefinição estrutural torna ao mesmo tempo invisíveis os limites de suas ações, tensionando a ordem do colégio por meio de suas pequenas intervenções cotidianas. Assim é que Ângela se dirigia ao escritório de Aristarco, "por motivos de recados" da patroa, e "cuja frequência desesperava o diretor". Nessas ocasiões, "um propósito de poças d'água em dias de chuva" obrigava "a saias curtas e canelas nuas" para deleite dos rapazes. Da mesma forma, D. Ema, "Bela mulher em plena prosperidade dos trinta anos de Balzac", foi considerada já de início pelo menino Sérgio "boa mãe para os meninos". No entanto, sua simples presença o atordoava,

8 A presença da filha do diretor não recebe, por parte do autor e/ou do protagonista, a mesma atenção que D. Ema e Ângela e não será, por isso, considerada neste ensaio. 


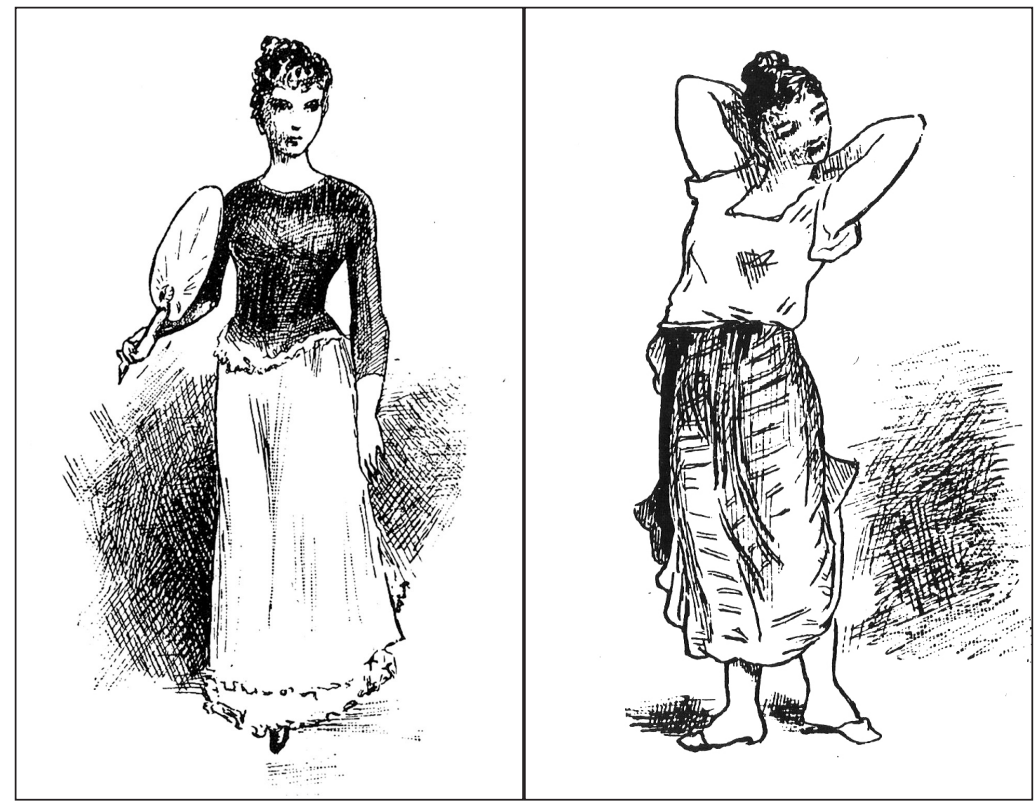

Figura 3 - D. Ema e Ângela.

Fonte: Pompeia (1993, p. 96 e 162).

dividido entre o amor e o cuidado maternal que a boa senhora evocava e a sedução de fêmea que seu corpo, vestes e gestos exalava.

Referindo-se à presença das duas mulheres no internato, o protagonista afirma que "Reinavam no Ateneu duas perniciosas influências [...] como a disseminação na sociedade, do princípio do mal". Assim, Sérgio evoca as "prédicas de ascetismo" de um colega para quem "o mal era fêmea" e para quem a cauda do demônio "era de rendas". A mulher, portanto, como "coisa horrível" e "destinada à perdição dos homens". Dessa maneira, "saia digna de consideração só a de padre", o mais não passando de "pretexto de moda parisiense para disfarçar o pé de cabra". A "teologia do Barreto" calou fundo no garoto, ficando-lhe no espírito a " teoria [...] do Satanás feminino", ratificada por episódio envolvendo a "canarina" Ângela. Esta, francamente sensual, tendo por costume se exibir ou se deixar ver pelos garotos "em corpinho e saia branca", foi motivo de crime passional que agitou enormemente o colégio:

Ângela tinha cerca de vinte anos; parecia mais velha pelo desenvolvimento das proporções. Grande, carnuda, sanguínea e fogosa, era um desses exemplares excessivos do sexo que parecem conformados expressamente para esposas da multidão - protestos revolucionários contra o monopólio do tálamo. (Pompeia, 1993, p. 95) ${ }^{9}$

9 O autor refere-se ao leito conjugal (tálamo) ou ao casamento e, nesse sentido, ao fato de que a camareira era um convite ao "protesto revolucionário" contra a instituição da 
Sobre a presença insinuante de Ângela no espaço do Ateneu, Sérgio afirma que "Os grandes pilheriavam; os pequenos, sérios, olhavam como quem aprende" e que, "Consciente da formosura, Ângela abusava" falando à imaginação dos homens no Ateneu:

[...] o olhar banhado de lascívia, a tempestade galopante das roupas, em desordem de fuga, calculada para efeitos de irritação, um descuido de alças afrouxadas ao corpinho; ora a uma porta em rápida passagem, ora através do parque frondoso; [...] ou sobre o muro da natação, ou a qualquer canto com os copeiros, em dueto de idílio que se espiava; ou em graçola aventurada aos inspetores, que se babavam. (idem, p. 90)

Era Ângela, portanto, quem despertava nos garotos do colégio as primeiras impressões destinadas ao sexo oposto, pois ela "dominava-os todos; vencia-os" e, em sua sensualidade, ao mesmo tempo ingênua (de menina) e calculada (de "segredo satânico"), "não escolhia amores", se "franqueando à concorrência":

[...] com os descuidos do corpinho, com as flores, com as turbulências de criança sem modos, Ângela era a rainha da atenção e da curiosidade [...] Se passava algum tempo sem aparecer, colavam-se [os meninos] às grades, perscrutando a sombra das árvores do quintal, carinhas sem conta, chupadas de saudade. (idem, p. 174)

Era através das janelas gradeadas que separavam o colégio do quintal da casa do diretor que os meninos espiavam a camareira:

Ângela fazia-se menina para brincar e correr com vivacidades de gata. Rolava no chão, envolvendo a cara nos cabelos soltos. Saltava agitando no ar as roupas; colhia flores e jogava, distribuindo por igual a todos, que ela a todos queria bem. Quando não havia muitos às grades do salão, descuidava-se, aparecia em corpinho e saia branca, afrouxando o cordão sobre o seio, mostrando o braço desde a espádua, espreguiçando-se [...] Sempre ao sol! sempre alegre! Filha selvagem da luz [...]. (idem, p. 173)

Já é amplamente sabido que a representação cultural do feminino nas sociedades tem sido a de uma identidade negativa "constituída essencialmente de proibições, que acabam gerando igualmente ocasiões de transgressão" (Bourdieu, 1999, p. 43). Essa "essência maléfica" ou esse preconceito que atribui uma natureza maligna às mulheres está diretamente ligado ao princípio da inferioridade e exclusão social da mulher; assim, vê-se no romance que a representação do feminino no colégio reflete e ratifica a da sociedade "lá fora".

Porém, para o protagonista, as duas mulheres no Ateneu representam também o "meato de passagem", isto é, o caminho ou meio que levava à possível fuga

monogamia. Coerentemente, a morte ocorrida no colégio se deu pela disputa (uma espécie de duelo) entre dois empregados da instituição pelo amor da moça. 
dos "embaraços pungentes" do colégio (os exames, o diretor, a inspeção dos bedéis etc.). Assim, elas significavam, em sua beleza e feminilidade, uma passagem em meio aos "espinhos" da vida colegial. É assim que D. Ema é, para Sérgio, a "amável senhora", "tão boa, tão boa, no seu carinho de enfermeira, de mãe". A relação do menino com D. Ema é, no entanto, também cercada de ambiguidade sexual, pois o menino se deixa encantar por sua presença:

Sonhei: ela sentada na cama, eu no verniz do chão, de joelhos. Mostrava-me a mão, recortada em puro jaspe, unhas de rosa, como pétalas incrustadas. Eu fazia esforços para colher a mão e beijar [...] Ela ria do meu desespero, mostrava-me o pé descalço, que a calçasse. [...] Calçá-la apenas! [...] numa tortura ardente de beijos, exalando eu próprio a alma toda em chama. (Pompeia, 1993, p. 170)

As impressões do menino sobre a esposa do diretor ultrapassam, assim, as de "mãe" e "cuidadora". Ela é a mulher desejada e inatingível, colocada em um jogo próximo-distante que atordoa Sérgio quando, por ocasião de moléstia, era levado à enfermaria do colégio e colocado sob os cuidados da mãe-enfermeira:

A porta da enfermaria descerrava-se devagarinho e na matinée de musselina elegante e frouxa aparecia a amável senhora. [...] Ema sentava-se. Pousava os cotovelos à beira do colchão, o olhar nos meus olhos- aquele olhar inolvidável, negro, profundo como um abismo, bordado pelas seduções todas da vertigem. Eu não podia resistir [...]. (idem, p. 201)

Embora socialmente distante, a proximidade de D. Ema nos dias de enfermidade fez o menino constatar que "A convivência cotidiana na solidão do aposento estabelecera [entre eles] a estranha familiaridade dos casais", sentindo, por essas ocasiões, "desesperada necessidade [da] companhia da boa senhora", e confessa não ter amado tanto assim a própria mãe. A enfermaria, onde Sérgio sentia-se "como em um ninho", era "um prolongamento" da residência de D. Ema, "um simples lance da casa [...], com entrada independente e comunicando por dentro com as outras peças".

Observemos, portanto, que D. Ema, exercendo o papel de enfermeira, uma função que extrapola o de "dona de casa" e de "esposa do diretor", não o faz senão como "prolongamento" do espaço que é, por definição, o seu como mulher e esposa: o da casa. Da mesma forma, não o faz senão de modo análogo ao papel que é socialmente/tradicionalmente atribuído às mulheres: o de mãe e cuidadora. Desse modo, observa-se também a delimitação arquitetônica do Ateneu no enquadramento das atividades masculinas e femininas: a enfermaria, como um braço externo de assistência às atividades internas do colégio, não deixa confundir as características dessas atividades, reforçando em sua estrutura física o sistema classificatório e simbólico que separa, correlativamente ao universo masculino/feminino, o fora/dentro, o público/privado e o racional/afetivo, pares de opostos que - paradoxalmente - estão ligados (da mesma forma que a enfermaria à casa da enfermeira).

A enfermaria do colégio constitui-se, portanto, como um espaço com atribuições semelhantes ao espaço doméstico, aquele cujo "regime" era exatamente 
aquilo do qual os meninos deviam ser separados para se constituírem homens. Desse modo, a enfermaria e sua enfermeira eram hiatos que suspendiam - embora apenas em parte - a rígida disciplina vivida no colégio, e por isso seu acesso seria somente obtido em ocasiões de exceção, como na ocorrência de moléstias. Marcada por relações de afeto e cuidados, tal como o "regime do amor doméstico", o espaço da enfermaria era paradoxalmente desejado a ponto de os garotos forjarem "imaginárias moléstias" para ter o direito de ali permanecer, usufruindo do zelo carinhoso de D. Ema, em uma suspensão temporária das exigências escolares. Quiçá, o espaço da enfermaria significasse, para muitos, uma espécie de volta aos braços maternos, contrariando dessa forma o projeto de desinfantilização ao qual estavam submetidos. "Infantilizados no enfraquecimento [da moléstia] como a recomeçar a vida" os meninos experimentavam, na enfermaria, sensações fragmentadas e contraditórias: "A convalescença progredia; era um desgosto", confessa o menino Sérgio.

Certamente não é possível, em texto de proporções tão curtas, expor com um mínimo de riqueza descritiva (para não falar da analítica) a complexa relação que se estabeleceu - sempre do ponto de vista do menino - entre Sérgio e a esposa do diretor do colégio. Talvez auxilie na compreensão dessa relação o fato de que foi o ambíguo sentimento pela boa senhora o que fez o protagonista declarar, em suas "memórias" (isto é, no romance), aquilo que talvez resuma o esforço daquela educação escolar e o seu pretendido resultado: Sérgio confessa/reconhece ter se tornado "um homem" após o idílio vivido.

Assim, após "erráticas" rotas como o menino bonito na solidão da clausura a ponto de sentir-se alvo ou motivo de desejo entre rapazes, Sérgio assoma decididamente por sobre as ondas revoltas das "indecisões de caráter" de menino

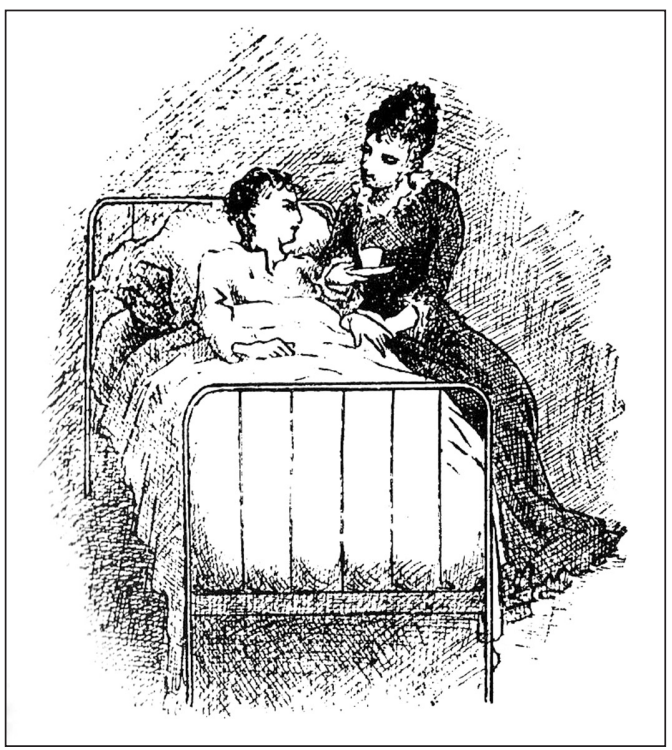

Figura 4 - Sérgio recebe cuidados de D. Ema na enfermaria. Fonte: Pompeia (1993, p. 197). 
imberbe que era quando chegou ao Ateneu e afirma sua condição de adulto: "De volta ao Ateneu, senti-me grande. Crescia-me o peito indefinivelmente, como se me estivesse a fazer homem por dilatação. Sentia-me elevado, vinte anos de estatura, um milagre". Essa passagem encerra a narrativa de um jantar na casa do diretor, com a presença de D. Ema ("miragem sedutora de branco" com "fartos cabelos negros" e, neles, uma "rosa vermelha"). A sensação de tornar-se grande ou, enfim, um homem, é tal que o menino verifica seus sapatos "a ver se haviam crescido os calcanhares". Não encontrando nenhum sintoma visível que atestasse o seu crescimento, o menino percebe que agora "olhava [...] para Egbert como para uma recordação e para o dia de ontem". Assim é que o menino, tomado agora pelo amor que devotava à D. Ema, considerava a amizade de Egbert: "coisa insuficiente" diante da "selvageria amordaçada de afetos". O querido amigo passou a lhe parecer "um intruso", e Sérgio "preferia andar só".

\section{CONSIDERAÇÕES COMPLEMENTARES}

Neste ensaio, tomando por locus um colégio de elite masculino descrito em um romance de inspiração autobiográfica, ${ }^{10}$ analisamos a trama social tecida em torno da construção social da masculinidade em oposição à feminilidade e, nessa construção, a proscrição da conduta homossexual. Paralelamente - e relativamente a essa construção tratamos da passagem, produzida pela vida escolar, da infância para a vida adulta mediada pela condição de aluno. Nesse duplo movimento de transformação de uma criança em adulto e, nesse caso, de um menino em homem, o que temos como pano de fundo ou como cenário das interações é a vida escolar em um internato, e, como veículo ou técnica que produz essa transformação, a disciplina que rege todo processo de socialização.

Assim, "fazer-se homem" (no Ateneu) implica um trabalho ininterrupto de construção de si diante dos outros e contra a feminilidade (por uma espécie de medo do feminino). Nesse sentido, a virilidade (como toda identidade) é uma noção eminentemente relacional (Bourdieu, 1999). A aprendizagem (das disposições necessárias à vida adulta), portanto, é o que propriamente realiza o trabalho social de eternização do arbitrário social (nesse caso, das estruturas da divisão sexual e seus princípios de divisão correspondentes), o que leva a reconhecer como inscritas em uma natureza (masculina/feminina) disposições e virtudes que são em verdade construídas ao longo de todo o processo de socialização (idem). Esse processo (trabalho histórico de desistoricização das estruturas sociais) que se baseia na diferenciação

10 Diversos estudos indicam que O Ateneu, como uma "crônica de saudades", contém elementos autobiográficos das experiências que Raul Pompeia vivenciou como aluno interno no colégio Abílio César Borges (Rio de Janeiro); no entanto o autor faz prevalecer em sua obra o caráter ficcional. O estudo biográfico de Capaz (2001, p. 106-123), comparando o romance à vida do romancista, indica diferenças em tal vivência, como a localização do colégio e a idade do protagonista Sérgio ao entrar no Ateneu relativamente à idade de Pompeia ao entrar no colégio Abílio. 
ativa em relação ao sexo oposto, no caso da identidade de gênero, também atua na diferenciação gradativa entre crianças e adultos.

A escola (assim como a família) é uma instituição socializadora por excelência e, para Bourdieu (idem), essas instituições, ao lado da Igreja, objetivamente orquestradas têm em comum garantir o trabalho de reprodução da vida social (ou o trabalho histórico de eternização das estruturas sociais), isto é, transmitir os pressupostos da representação patriarcal (baseada na homologia entre a relação mulher/homem e a relação adulto/criança). ${ }^{11}$ Assim, em nossas sociedades, a família patriarcal - e seu pressuposto, a dominação masculina ou a visão androcêntrica do mundo - é o princípio e modelo da ordem social como ordem moral fundamentada na preeminência absoluta dos homens sobre as mulheres e dos adultos sobre as crianças.

Para Bourdieu (idem, p. 41):

As divisões constitutivas da ordem social e, mais precisamente, as relações sociais de dominação e de exploração que estão instituídas entre os gêneros se inscrevem, assim, progressivamente em duas classes de habitus diferentes, sob a forma de hexis corporais opostos e complementares e de princípios de visão e de divisão que levam a classificar todas as coisas do mundo e todas as práticas segundo distinções redutíveis à oposição entre o masculino e o feminino.

Por fim, cabe destacar aquilo que Bourdieu (idem, p. 64) pondera a respeito da "cilada" social que pode também significar o "privilégio masculino". Enquanto ser dominante, os homens estão sujeitos a tensões e contenções permanentes e que são por vezes levadas a extremos no processo que impõe a todos "o dever de afirmar, em toda e qualquer circunstância, sua virilidade”. Assim, poder-se-ia afirmar que "a virilidade, entendida como capacidade reprodutiva, sexual e social [...] é, acima de tudo, uma carga”. Ou seja, não é por ser o lado privilegiado da relação entre os sexos que os homens não sofram com as imposições sociais de defender, a qualquer custo, seu papel social.

Uma breve reflexão sobre as implicações da atual perda do poder masculino (poder paterno, conjugal, sexual etc.) no processo contemporâneo do chamado "declínio da autoridade" no quadro das transformações das centrais instituições sociais, ou, ainda, a violência (simbólica e física) de que são alvo os homossexuais assumidos nas sociedades de hoje, nos ajudaria a compreender este que nos parece um paradoxo e que, no entanto, reflete a dialética de uma relação social baseada na diferença e na desigualdade (tomadas em sua suposta natureza e imutabilidade), que é a relação que temos socialmente construída entre homens e mulheres (e entre adultos e crianças).

11 Bourdieu (1999, p. 105, grifos do original), ao recensear os fatores institucionais da reprodução da divisão dos gêneros sexuais, analisa também o papel do Estado "que veio ratificar e reforçar as prescrições e as proscrições do patriarcado privado com as de um patriarcado público, inscrito em todas as instituições encarregadas de gerir e regulamentar a existência quotidiana da unidade doméstica”. 


\section{REFERÊNCIAS}

Ariès, P. Historia social da criança e da família. Tradução de Dora Flaksman. 2. ed. Rio de Janeiro: LTC, 1981.

Bourdieu, P. Le sens pratique. Paris: Éditions de Minuit, 1980.

. As regras da arte: gênese e estrutura do campo literário. Tradução de Maria Lúcia Machado. São Paulo: Companhia das Letras, 1996.

. A dominação masculina. Tradução de Maria Helena Kuhner. Rio de Janeiro: Bertrand Brasil, 1999.

Science de la science et reflexivité: cours du Collège de France 2000-2001. Paris: Raisons d'Agir Éditions, 2001. Seuil, 2002.

La domination masculine: edition augmentée d'une preface. Paris: Éditions du

Capaz, C. Raul Pompéia: biografia. Rio de Janeiro: Gryphus, 2001.

Comenius. Didática magna. Tradução de Ivone Castilho Benedetti. São Paulo: Martins Fontes, 1997.

Foucault, M. Surveiller et punir: naissance de la prison. Paris: Gallimard, 1975.

História de sexualidade: a vontade de saber. Rio de Janeiro: Graal, 1988.

Pascal, B. Pensées: texte établi par Louis Lafuma. Paris: Éditions du Seuil, 1962.

Perrenoud, P. Ofício de aluno e sentido do trabalho escolar. Porto: Porto Editora, 1995.

Pompeia, R. O Ateneu: apuração do texto em confronto com o original e introdução por Therezinha Bartholo. Rio de Janeiro: Francisco Alves, 1993.

ProençA, I. C. Introdução. In: Pompeia, R. O Ateneu: crônica de saudades. Biografia, introdução e notas de Ivan Cavalcanti Proença. Rio de Janeiro: Nova Fronteira, 2011.

SAntos, T. R.; Marchi, R. C. O contágio da convicção: os ritos de instituição n'O Ateneu e a propagação da crença escolar. Revista Portuguesa de Educação, Braga: Universidade do Minho, v. 26, p. 37-57, 2013a.

;_ __ Ateneu: uma análise dos mecanismos disciplinares no romance de Raul Pompeia. Educação E̋ Realidade, Porto Alegre: UFRGS, v. 38, p. 339-360, 2013b. .; — O disciplinamento do espírito: uma análise dos ritos de instituição no romance O Ateneu. Educação, Porto Alegre: PUC-RS, v. 36, p. 96-106, 2013c.

\section{SOBRE OS AUTORES}

Rita de Cássia Marchi é doutora em sociologia política pela Universidade Federal de Santa Catarina (UFSC). Professora da Fundação Universidade Regional de Blumenau (FURB).

E-mail:rt.mc@bol.com.br

Tiago Ribeiro Santos é doutorando em educação pela Universidade Federal de Santa Catarina (UFSC).

E-mail: tiago.ribeiro@live.com 